\title{
NORTH CAUCASUS IMAGE INSIDE RUSSIA IN THE CONTEXT OF TOURISM CLUSTER DEVELOPMENT
}

\author{
Tatiana LITVINOVA* \\ Moscow State Institute of International Relations, Department of Regional Governance and National \\ Politics, 143000, 3, Odintsovo, Novo-Sportivnaya st., Russia, Moscow region, e-mail: tantin@mail.ru
}

\begin{abstract}
Citation: Litvinova T.N. (2020). NORTH CAUCASUS IMAGE INSIDE RUSSIA IN THE CONTEXT OF TOURISM CLUSTER DEVELOPMENT. GeoJournal of Tourism and Geosites, 28(1), 275-288. https://doi.org/10.30892/gtg.28122-469
\end{abstract}

\begin{abstract}
The article is devoted to the North Caucasus image assessment inside Russia as the important factor of tourists' attraction to this territory. The growth of tourist cluster in the North Caucasus is one of the main tasks written in Strategy of socio-economic development of the North Caucasus Federal District untill 2025. But in the public opinion of Russians the North Caucasus was for many years perceived as a territory of socio-political instability. The research is based on the Internet survey conducted by author $(n=1012)$. The results of survey are matched with mass media news about tourist objects development and also compared with statistic of visits of the North Caucasus by Russian and foreign citizens. The conclusion says about the growth of positive assessments of the North Caucasus image among Russians, but some stereotypes still remain. The ski resorts in Dombay and Elbrus region, which are in demand among lovers of skiing, need modernization and expansion of infrastructure. Recreational resources of cultural and ecological tourism of the republics of the North-East Caucasus are poorly used. Statistics show that the resorts of the Krasnodarsky krai constitute serious competition to the North Caucasus.
\end{abstract}

Key words: territory image, tourism cluster development, public opinion, internal tourism, North Caucasus

$* \quad * * * * *$

\section{INTRODUCTION}

The dynamic changes of last years are followed with the growing mobility of citizens, financial, material and intangible resources, which are basic factors of economic growth. The government of the Russian Federation faces a serious challenge to revise the methods and tools of management and development of its regions. The North Caucasus Federal District of Russia includes seven subjects inhabited by different peoples and ethnic groups: the Kabardino-Balkarian Republic, the Karachay-Cherkessia Republic, the Republic of Ingushetia, the Chechen Republic, the Republic of North Ossetia - Alania, the Republic of Dagestan and Stavropol krai. The region is rich in natural and recreational resources, but characterized by the presence of a significant number of socio-political

\footnotetext{
* Corresponding author
} 
problems. The North Caucasian republics have rather low socio-economic indicators compared to other regions of the country. Thus, according to the Federal State Statistics Service, monthly per capita cash income in the North Caucasus Federal District for the first quarter of 2019 amounted to 279 euro, which is lower than the average all-Russian indicator (411 euro) and the average indicators of the neighboring South Federal District - 337 euro (Federal State Statistics Service, 2019). The lowest monthly income of population showed Republic of Ingushetia, Karachay-Cherkessia Republic and Kabardino-Balkarian Republic. One of the serious problems of the North Caucasus region is unemployment, especially among youth. An excess of young economically active population with an insufficiently developed production infrastructure is a serious problem for further socio-economic growth. That's why the priority task is to strengthen the economic positions of the North Caucasus of the Russian Federation.

For this purpose, in the "Strategy of socio-economic development of the North Caucasus Federal District until 2025" (2010), tourism sector was designated as one of the directions for the North Caucasus development, mainly in the ski and mountain cluster. Further development of tourism in the North Caucasus, the creation of an appropriate infrastructure and management system can provide jobs for unemployed youth and a development impetus for new business entities. The "Strategy of the socio-economic development of the North Caucasus Federal District until 2025" (2010) identifies regional problems that currently hamper the development of tourism in the North Caucasus: first of all, this is a security problem, as well as functional problems such as a low level of service and a low level of development of the transport network, low hotel availability, poor distribution of the international hotel classification system in the North Caucasus, negative image of the North Caucasus Federal District. Holland (2016) conducted a retrospective analysis of the content and objectives of the "Strategy" correlating them with the economic opportunities of the region. He noted that the North Caucasus has a significant natural base: highlands of the Greater Caucasus, the coast of the Caspian Sea and mineral springs in the Stavropol krai, Kabardino-Balkaria and Karachay-Cherkessia.

At the same time, E. Holland said: "Tourism infrastructure in the region remains underdeveloped, however, and the "Strategy" identifies the ongoing security threat as limiting investment in this sector" (Holland, 2016, 53). The North Caucasus can provide a variety of leisure activities from the snowy peaks of Elbrus in the west to the Caspian Sea in the east of the region and, first of all, this territory should become an object of attraction for Russian tourists. But in the public opinion of Russians, the North Caucasus for many years was perceived as a territory of socio-political instability and ethnic conflicts with a high level of terrorist threat. Obviously, breaking these stereotypes in the minds of people and creating a positive image of the North Caucasus within the country is a rather difficult task. The aim of this study is the assessment of the North Caucasus image inside Russia as a factor of the tourist cluster development in the region.

One of the latest policy documents setting new goals for governance offered the new approach to the regional development. On February 13, 2019, the Government of the Russian Federation approved the "Strategy of the spatial development of the Russian Federation for the period until 2025" (2019). This document proposed a new mechanism for the territories' economic growth with a special regime for doing business, taking into account promising specializations of specific subjects of the Russian Federation.

The Strategy of the spatial development in the number of other priorities for the North Caucasus macroregion named the tourism sector development and some connected spheres such as: the creation of new development institutions, including special business regimes; assistance in the preservation and development of traditional folk crafts; increase in passenger and freight traffic through seaports and international checkpoints 
in the Caspian Sea. According to the Passport of the State Program "Development of the North Caucasus Federal District" (2019), the budget allocation to the regional economy in 2019-2022 will be approximately 1.2 billion euros (including 356.8 million euros for tourist cluster). The planned volume of attracted investments to the North Caucasus economy for 2020-2025 in addition to budget funds will amount to 2.2 billion euros.

The developed tourism sector stimulates economic growth in the region, helps to attract investment, and, ultimately, leads to the welfare increase of the population. Spatial development lays the foundation for comparing regions of Russia in terms of attractiveness for life, doing business, investment, and developing tourism. In Russia, with its wealth of natural and cultural objects, tourism is considered as one of the priority sectors. However, in order to increase the influx of tourists and income in this area, it is necessary to form the appropriate infrastructure, as well as to create a positive image, not only of the country as a whole but of its variouse regions.

\section{MATERIALS AND METHODS}

The theoretical foundations of the study of the territorial image were laid by the works of P. Kotler, a recognized specialist in the field of places marketing. Territorial marketing is the most effective tool for creating a competitive and attractive image of a particular place. Kotler et al. defined the “country image” as „sum of people's beliefs, ideas and impressions about a certain country" (2002, 141). A rapid increase of the product diversity in the previously non-commercial fields has led to the greater attention paid to the image and the brand of the territory (Matlovicova et al., 2019). Territorial image has become the object of not only marketing but also geografic studies. Geographers focus on a purposeful geographic brand building policy, which requires appropriate adaptation of brand concept and the creation of institutional structures to ensure this activity (Matlovic \& Matlovicova, 2012, etc.). Modern tourism management was expanded with the new directions of research of territorial (destination) image from the micro-level (city, town, destination) and meso-level (republic, district) to the macro level (country, continent) (Novenkova \& Kalenskayaa, 2015). It is first of all connected with the concept of sustainable tourism and analysis of the environment system within destination areas (Hunter, 1997). The second approach is practical solutions in response to the challenge of reinventing spatial and territorial development planning through digital transformation, using smart tools: territorial development indexes and quantitative analyses (Visan, 2019).

The image of a country (region, territory) is formed at several levels: household, socio-economic, business, financial and others. It is also extremely important from the point of view of those who live in the country. The psychological aspects of the perception of the territory have particular importance: the desire to live on it, a sense of comfort and security, the expectation of a prosperous future for yourself and your children, the desire to visit, do business. There are two sides to the image of the territory: the internal image, "what citizens think about their own country," and the external, "what others/foreigners think about the country" (Jenes, 2008, 67). In the case of the North Caucasus, which is part of Russia, we are still forced to state that for many citizens who do not live in the south of Russia, it is a strange and distant. According to the research of another recognized place branding specialist Anholt (2013), when forming a national image, it is necessary to take into account that most people tend not to change their opinion about a particular country, and their opinion may be adequate to reality or completely distorted.

It is formed on the basis of stereotypes, historical circumstances and relations with other states. In cases where opinion changes, it changes gradually and the process can take decades. Image building is a long process that can be compared with a collective project, it brings results only in the long term, requires a clear strategy, action plan and 
coordination. Although there are various methods and ways to improve the image of the territory, "but that better image can only be earned; it cannot be constructed or invented" (Anholt, 2008, 2). Echtner \& Ritchie (1993) investigated the destination image and tried to propose the appropriate techniques for its measurement which included images, holistic impressions, and functional characteristics of the place, and also psychological characteristics. They conclude that to form a successful image of the territory and increase its tourist attractiveness, the destination must clearly differ from its competitors, must have a strong position in the minds of people and the memories of tourists.

Stavropol scientists Andreyanova \& Ivolga (2018) addressed their study to the potential for tourism development in the North Caucasus. Their methodology was based on the investigation of various nature zones in the region, analysis of the socio-economic development of the territories and their tourist attractiveness. They named the following most popular tourism destinations:

- spa holidays;

- pilgrimage;

- mountain and ecological tourism;

- cultural tourism.

At the same time, they identified the following internal problems hindering the tourism development in the North Caucasus: 1) low development of infrastructure, including in areas where objects of attraction are located; 2) linguistic and cultural barriers; 3) management errors in the development of the tourism industry; 4) although the current political situation is quite stable, the "shadow" of the Chechen war and other regional conflicts (Andreyanova \& Ivolga, 2018). A lot of articles of the North Caucasian authors were devoted to the resort potential of separate republics: Dagestan (Matyugina et al., 2019), North Ossetia (Bestaeva \& Kodzaeva, 2018), Ingushetia (Pogorova \& Dudurgova, 2019). They argue that the tourist and recreation potential of republics is still low used. The image of the region consists of people's ideas about its population, economy, leaders, architecture and cultural objects, history, geography and landscape. The most important image-building tool is the media, and in recent years, mainly online publications and social networks. It reinforces the meaning of network research of people's perceptions of a particular geographical location (Stepchenkova \& Morrison, 2006).

Among recent publications on the North Caucasus image there is the work of Yezhova \& Maslyuk (2018). They analyzed the content of publications on the personal pages of Vkontakte (Russian popular social network service), Facebook and Twitter users. Their study came to the conclusion that the image of the North Caucasus as a region of Russia inside country, mostly negative, it is associated among users with ethnic conflicts and military incidents. At the same time, positive associations dominate in the internal image of the North Caucasus among those who live in region: traditional values, respect for elders, friendship, religion, crafts, unique natural objects and history. From their investigation we can see the gap between external views and local residents' perseptions. While there are many studies studying the external image of the territory, limited attention is paid to the analysis of local residents based on their perception of the place in which they live as a tourist destination (Stylidis, 2018).

To manage special economic zones in the tourism cluster of the North Caucasus Federal District, Decree of the Government of the Russian Federation of October 14, 2010 No. 833 established the Joint-Stock Company "Resorts of the North Caucasus". At present, it oversees six projects, mostly in the skiing sector: "Armkhi” and "Tsori” in Ingushetia, „Arkhyz” in Karachay-Cherkessia, „Veduchi” in Chechnya, „Elbrus” in Kabardino-Balkaria, Caspian coastal cluster and „Matlas” in Dagestan (Figure 1). For the period 2015-2025 JSC "Resorts of the North Caucasus” planned to create 14.2 thousand 
placements at these facilities and attract 53.7 billion rubles of private investment (Resorts of the North Caucasus, http://www.ncrc.ru). The development of the tourism sector will increase the tax collection of residents in the budgets of the republics of the region. However, the success of these projects directly depends on the influx of tourists. The official website of the JSC "Resorts of the North Caucasus" has the news line which informs about tourist cluster development in very positive tone. On the contrary the online news site „Caucasian Knot” (Kavkazskii Uzel) publishes more negative news about problems that tourist objects face (Caucasian Knot, https://www.eng.kavkaz-uzel.eu/). Monitoring of online media can give us the contradictory but interesting materials for analisys and they also influece the North Caucasus image.

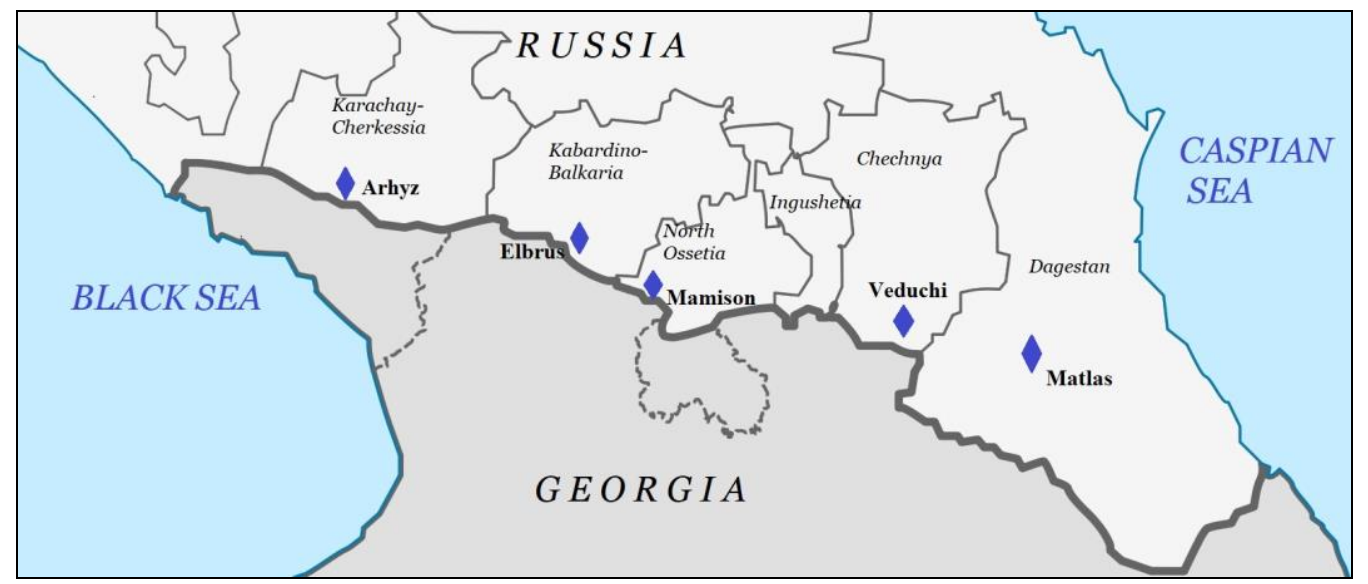

Figure 1. The planned ski resorts in the North Caucasus republics

The informative source for assessement the North Caucasus image inside Russia can be a sociological survey. To find out the possibilities of creating a positive image of the North Caucasus in order to increase its tourist attractiveness, we conducted an online survey "Image of the North Caucasus inside Russia" $(n=1012)$ on the Webanketa platform.

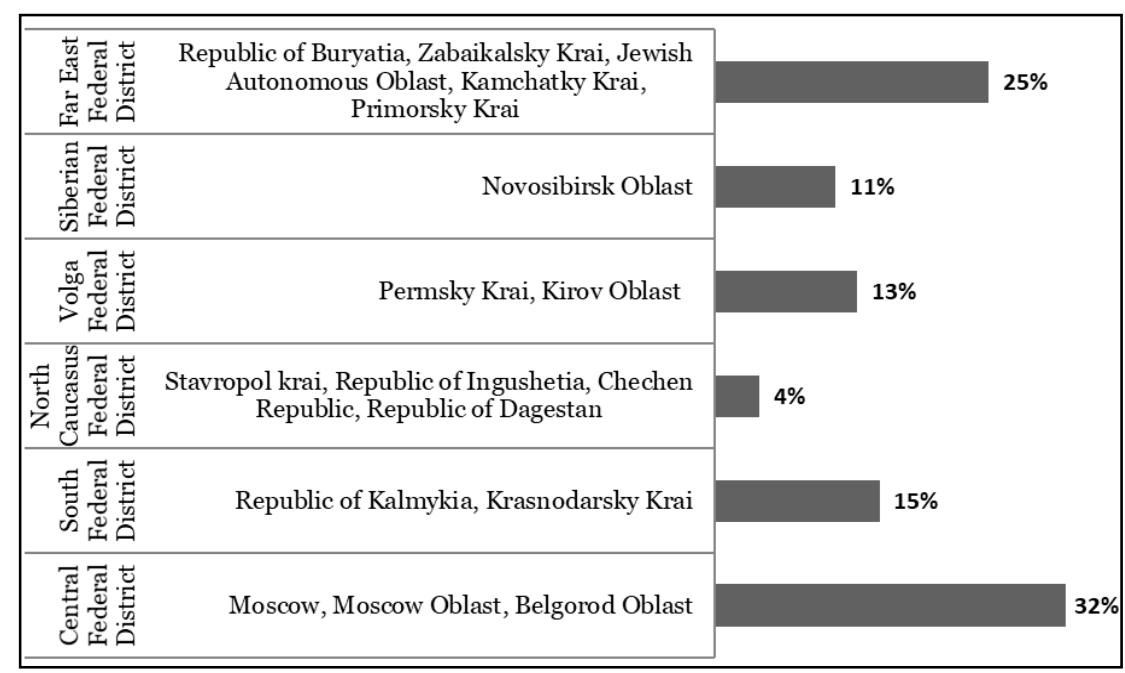

Figure 2. Distribution of respondents surveyed by territory of residence 
The survey covered residents of 16 subjects of the Russian Federation from diffrent parts of our country (Figure 2): Central Federal District, Volga Federal District, South Federal District, Siberian Federal District, and Far East Federal District. Among the respondents, 4\% were residents of the North Caucasus Federal District (Stavropol krai, Republic of Ingushetia, Chechen Republic, Republic of Dagestan).

Among participants of survey there were $46 \%$ of men and $54 \%$ of women. The age of respondents is from 17 to 69 years. The disadvantages of the sample are that more than half of the respondents (53\%) were young people aged 17-29, $29 \%$ of respondents were people from 30 to 45 years old, $18 \%$ were over 45 years old. The difficulty of following sampling quotas by age and gender of respondents is one of the significant difficulties of online surveys. On the other hand, young people have greater chances to travel to the North Caucasus for tourist purposes. The proposed questionnaire focused on ascertaining the awareness of respondents about the current situation in the republics of the North Caucasus, associations that arise when the North Caucasus is mentioned in the media.

We were interested in whether the respondents were considering the opportunity to go to the North Caucasus, and what types of recreation they would prefer for this trip. But before presentation of the survey results, we shall observe the official statistics of visits of Russians and foreigners in the republics of the North-Caucasian Federal District to compare it with the public opinion and mass media publications. So the research is based on the above mentioned methods: 1) statistics data analisys; 2) monitoring and content-analisys of mass media; 3) online survey conducted by the author.

\section{RESULTS DISCUSSIONS}

The subjects of North West and North East Caucasus differ in set of recreational resources and tourist infrastructure readiness. The Stavropol krai is famous territory rich in mineral waters with resorts well known since the $19^{\text {th }}$ century. A number of mountainskiing facilities in Karachay-Cherkessia and Kabardino-Balkaria have been known and popular among lovers of mountain-skiing and mountaineering since the Soviet period. This is Dombay mountainous territory in Karachay-Cherkessia and Elbrus region a balneoclimatic resort area in Kabardino-Balkaria. With the start of the project "Resorts of the North Caucasus", the young "Arkhyz" ski resort in Karachay-Cherkessia is gaining popularity, which has certain prospects of becoming a modern center for mountaineering and recreation. As for the North East Caucasus the tourist infrastructure of Chechnya, Ingushetia, North Ossetia and Dagestan is still in progress. So these republics are not so popular for torist visits. The dynamics of tourism of Russian citizens in the North Caucasus Federal District is shown by official statistics on the number of Russian citizens who stayed in collective accommodation facilities (hotels, resorts, campings, etc.) from 2013 to the first half of 2019 (Table 1). The table shows an increase of $43 \%$ in the number of Russians in collective accommodation facilities in the regions of the North Caucasus, but we see that the leaders in the number of annual visits are Stavropol krai, KabardinoBalkaria and Karachay-Cherkessia. However, we should remember the fact that resorts and sanatoriums of the Krasnodar krai (including mountain skiing) in Sochi and Krasnaya Polyana constitute significant internal competition to the resorts of the North Caucasus.

The dynamics of domestic tourism in accommodation facilities in the North Caucasus showed dependence on international sanctions. So, in the winter season of 2014-2015 „Arkhyz” resort was visited by 90 thousand guests, which exceeded the tourist flow of the previous reporting period by 2.5 times. That year, the Minister of North Caucasus Affairs L.

Kuznetsov said that "given the noticeable reorientation of the tourist flow to domestic resorts" - the demand for holidays in Karachay-Cherkessia and Kabardino-Balkaria grew by 20\% (More than 230 thousand people visited „Arkhyz” resorts in Karachay-Cherkessia and 
„Elbrus-Berezengi” in Kabardino-Balkaria (in the Elbrus region) during the winter season, 2015). However, statistics on the number of Russian citizens who used collective accommodation facilities in the North Caucasus Federal District for 2015 as a whole shows a decrease in all republics, including Karachay-Cherkessia and Kabardino-Balkaria.

The growth of tourist accommodation dynamics began in the next 2016, and by the end of 2018, 120 thousand Russian tourists visited the Kabardino-Balkarian Republic, 102 thousand Russians - the Karachay-Cherkessia Republic. Official statistics (Table 1) show that the Chechen Republic has the largest growth of the annual number of Russians staying in hotels and other facilities for 2013-2018 (almost 3 times). In the first half of 2019, the republic was visited by twice as many guests as in the whole of 2013.

Table 1. The number of citizens of the Russian Federation placed in collective accommodation facilities, thousand people (Data source: EMISS. State statistics, 2019, https://fedstat.ru/indicator/44040)

\begin{tabular}{|c|c|c|c|c|c|c|c|}
\hline Region & 2013 & 2014 & 2015 & 2016 & 2017 & 2018 & $\begin{array}{c}\text { January- } \\
\text { June 2019 }\end{array}$ \\
\hline North Caucasus Federal District & 1102,5 & 1146,7 & 1069,4 & 1368,52 & 1401,08 & 1584,5 & 747 \\
\hline The Republic of Dagestan & 79,1 & 69 & 67,4 & 138,32 & 113,57 & 184,1 & 58,8 \\
\hline The Republic of Ingushetia & 5,6 & 8,5 & 3 & 2,59 & 7,03 & 10 & 3,9 \\
\hline Kabardino-Balkarian Republic & 85,5 & 87,5 & 84,9 & 104,6 & 117,36 & 120,4 & 61,2 \\
\hline Karachay-Cherkess Republic & 86 & 101,6 & 77,3 & 113,71 & 99,08 & 102,1 & 65,9 \\
\hline Republic of North Ossetia - Alania & 52,1 & 43,3 & 39,7 & 40,91 & 51,27 & 67,9 & 32,2 \\
\hline Chechen Republic & 24,3 & 33,8 & 29,4 & 30,57 & 55,41 & 65,6 & 46,9 \\
\hline Stavropol krai & 769,9 & 803,1 & 767,8 & 937,82 & 957,36 & 1034,3 & 479,1 \\
\hline Krasnodar krai (South Federal District) & 2463,2 & 3649 & 5233,5 & 5662,6 & 6451,4 & 7820,9 & 2463,2 \\
\hline
\end{tabular}

For comparison, we cite data on the placement of foreign citizens in hotels, resorts and campings of the North-Caucasian Federal District subjects for 2013-2018. The number of visits by foreign citizens during this period almost doubled. However, the dynamics of visits by foreign citizens to individual republics is very uneven.

For example, in Kabardino-Balkaria, the annual number of foreign guests is almost tripled (from 1.7 thousand people in 2013 to 6.2 thousand people in 2018), but in Karachay-Cherkessia the annual number of foreign guests in collective accommodation facilities almost halved by 2018 (from 2 thousand people to 1.1 thousand people).

Over the same period, the annual number of foreign guests in the Chechen Republic has grown in almost five times (from 1.2 thousand to 5.8 thousand). In Dagestan, we see a jump in visits by foreigners in 2015, which was associated with the celebration of the 200oth anniversary of the oldest city of Russia, Derbent (Table 2).

Table 2. The number of foreign citizens placed in collective accommodation facilities, thousand people (Data source: EMISS. State statistics, 2019, https://fedstat.ru/indicator/44042)

\begin{tabular}{|l|c|c|c|c|c|c|c|}
\hline \multicolumn{1}{|c|}{ Region } & 2013 & 2014 & 2015 & 2016 & 2017 & 2018 & $\begin{array}{c}\text { January- } \\
\text { June 2019 }\end{array}$ \\
\hline North Caucasus Federal District & 36,0 & 43,3 & 67,1 & 49,8 & 56,9 & 65,8 & 28,1 \\
\hline The Republic of Dagestan & 1,0 & 1,8 & 8,9 & 1,1 & 2,4 & 3,2 & 1,0 \\
\hline The Republic of Ingushetia & 0,2 & 0,1 & 1,0 & 0,5 & 1,3 & 1,2 & 0,4 \\
\hline Kabardino-Balkarian Republic & 1,7 & 2,3 & 4,2 & 2,8 & 5,4 & 6,2 & 2,6 \\
\hline Karachay-Cherkess Republic & 2,0 & 2,0 & 3,9 & 1,7 & 0,8 & 1,1 & 0,7 \\
\hline Republic of North Ossetia - Alania & 0,6 & 2,2 & 1,2 & 1,8 & 1,6 & 2,0 & 1,0 \\
\hline Chechen Republic & 1,2 & 0,4 & 3,2 & 2,5 & 2,1 & 5,9 & 1,8 \\
\hline Stavropol krai & 29,2 & 34,6 & 44,6 & 39,3 & 43,2 & 46,2 & 20,7 \\
\hline Krasnodarsky krai (South Federal District) & 77,3 & 288,6 & 326,8 & 143,6 & 171,4 & 230,1 & 116,5 \\
\hline
\end{tabular}


In their study of the international tourism to Russia L. Andrades and F. Dimanche (Andrades \& Dimanche, 2017) made a conclusion that despite great potential, tourism development in Russia had met many challeges such as: destination image, infrastructure development, workforce training and education, quality management, and sustainable management. Further more, they also rightly noted that Russia, the largest country in the world, should develop tourism consistently from East to West paying attention to regional perspective. Meanwhile, many recreation areas of the North Caucasus encounter serious difficulties in their development, both those which have long been established and those are only gaining popularity among tourists. For example, the "Dombai" resort, unlike the "Elbrus" resort, was not included in the JSC "North Caucasus Resorts".

Admiring the beauty of the mountains, tourists often note the presence of garbage and some problems with the infrastructure in Dombay. In turn, the implementation of the "Elbrus" project was faced with the problem of unresolved land relations in the Kabardino-Balkarian Republic. Owners of small hotels, cafes, restaurants, rentals and other enterprises that have been working for decades have not been able to register land or building rights and obtain a resident status, and have lost the possibility of tax benefits, and are at risk of losing their business. In the early days of 2019, due to the large flow of tourists on the ski slopes of "Elbrus", large lines formed. Vacationers reported in social networks that in the early days of the new year, a rush of crowds occurred in the resort, and traffic jams formed at the entrance to the foot of Elbrus mountain. In July 2019 Caucasian Knot published "The construction of new routes and cable cars in the "Elbrus" resort was estimated at $\$ 5.7$ billion" (https://www.kavkaz-uzel.eu/articles/337492/).

At the same time, media often reports that the part of the territory of the "Elbrus" resort belongs to the lands of the national ecological park of Elbrus region, on which it's prohibited to build sports facilities (TASS: The development of the Elbrus resort in the KBR depends on the solution of the land issue, 2019). The special geo-ecological situation created in the Caucasus requires special environmental management, an integrated approach to targeted use and management, which provides for the identification of environmental risks caused by natural and man-made impacts (Tsereteli et al., 2011).

Difficulties in development are also experienced by the territories of the North-East Caucasus, which have only recently declared themselves as new objects of attraction for mountain-skiing tourism. Ambiguous news appeared about the „Veduchi” resort in the Chechen Republic, opened for tourists in early 2018. Due to the insufficient snow cover, the republic's authorities had to arrange snow delivery during the winter holiday period (The ski season at the „Veduchi” resort began with artificial snow, 2019).

Another pressing problem is that the resort mainly employs imported personnel from other regions, so the development of the tourism cluster in Chechnya does not solve the problem of employment of local youth yet. Among Chechens, it is traditionally considered shameful to serve and work in the service sector. Most preferred employment for men is the army, law enforcement, government, for women is household and outside the house teaching. In May 2018, JSC "Resorts of the North Caucasus" declared about postponing the implementation of two projects in Ingushetia, "Tzori" and "Armkhi", as well as a project in Dagestan "Matlas", as far as corporation will deal with facilities that has been already launched such as "Arkhyz" in Karachay-Cherkessia, "Elbrus" in Kabardino Balkaria and "Veduchi" in Chechnya (http://www.ncrc.ru/press-center/publikatsii /publik atsii-smi/ia-regnum-realizatsiya-kurortov-armkhi-tsori-imatlas-otodvigaetsya-na-2023-god. html? sphrase_id=7282). For some time, the implementation of the „Mamison” allseason resort project in the Republic of North Ossetia-Alania was also frozen. It is still hard to imagine that the tourist flow for sanatorium and skiing holidays in all the republics of the North Caucasus will increase so much that the turn will come to these projects. 
The most obvious reason why the resorts of the North-East Caucasus are developing more slowly and less successfully is the high competition with resorts in the North-West Caucasus and the neighboring Krasnodar krai. Their recreational advantages are largely leveled with the territorial proximity of already developed recreational complexes. Regional authorities hope to make their republics places of attraction for the ski cluster, but in this situation, it is better to bet on alternative types of recreation and specialized facilities of individual republics as unique recreation areas, especially since there are such facilities (Figure 3). For example, Ingushetia and North Ossetia possess not only recreational opportunities comparable to neighboring republics, but also unique historical monuments. A striking architectural object in Ingushetia is the medieval tower complex of Vovnushki. On the territory of the Republic of Ingushetia is the Christian temple of Thaba-Erdy built in the 8th - 9th centuries (Pogorova \& Dudurgova, 2019). The Republic of North Ossetia-Alania is also rich in cultural objects: in the Alagir district there is a shrine of the Ossetian people - Grove Khetaga, in the village of Nuzal there is a chapel of the 10th century with preserved wall paintings, Alansky Holy Assumption Monastery (the highest monastery in Russia) and many other objects (Bestaeva \& Kodzaeva, 2018).

Dagestan also presents the historical and cultural heritage which can attract tourists. Unique place is the oldest city in Russia, Derbent, listed in the UNESCO World Heritage sites (Beck, 2006). In Dagestan there are also the Dzhuma Mosque in the village of Kumukh (XIII century), the high-mountain village fortress Kala-Koreish (XI century), the remains of the Russian fortress in Nizhny Gunib from the time of the Caucasian war and other objects (Matyugina et al., 2019).

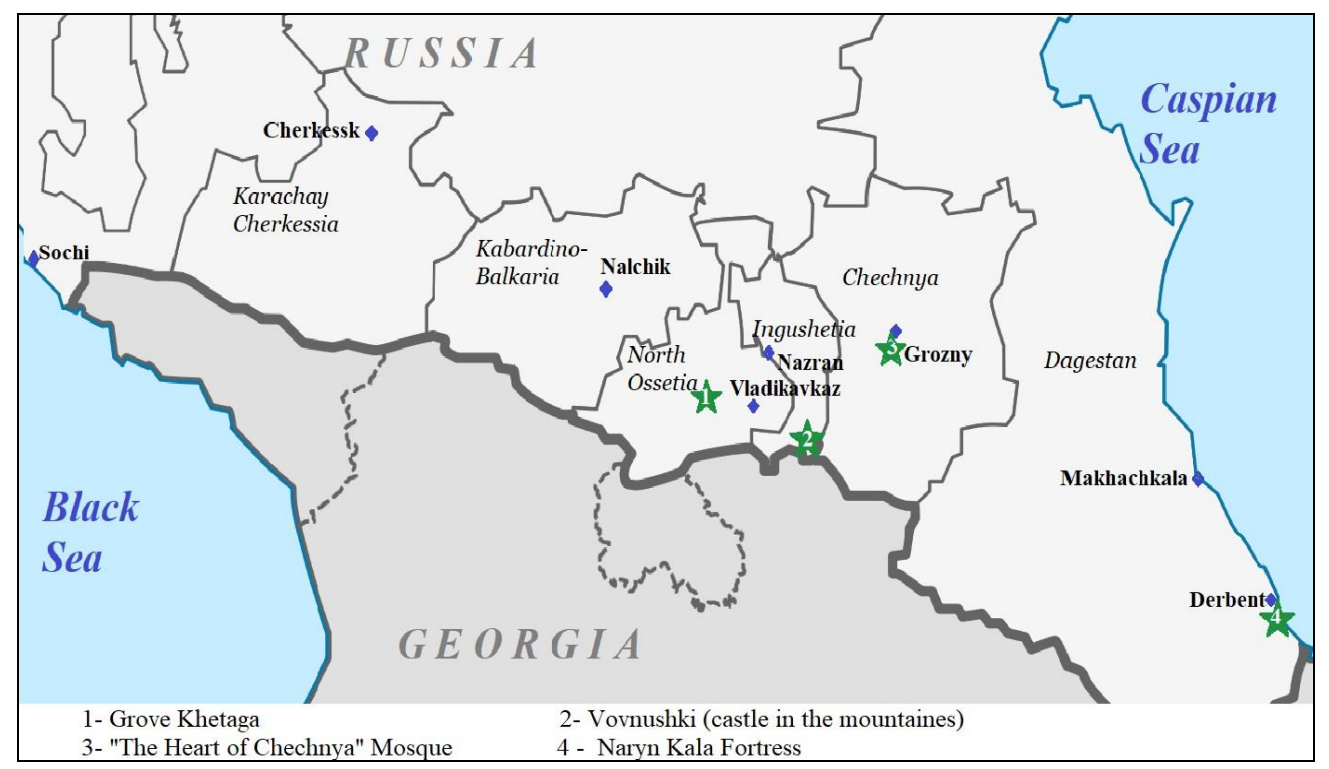

Figure 3. Natural and cultural heritages of the North Caucasus

One of the competitive advantages of the Republic of Dagestan is access to the sea; the swimming season on the Caspian Sea lasts more than four months. In the Caspian region, there are all balneological groups of mineral waters. Over 300 mineral springs have been identified, and for health cures purposes only 5 wells are used near by Makhachkala. Mineral water sources in Pyatigorsk and Zheleznovodsk (Stavropol krai) are the closest undisputed competitors. Assessing the image of the North Caucasus inside Russia, we asked 
respondents about the main associations that they have when they hear about the region. The answers are dominated by geographical (mountains, Elbrus, Caspian) and culturalhistorical (Islam, highlanders, Lezghinka, Dzhigits) associations. The third place in the associative row was occupied by the Chechen conflict of the 1990 ( $44 \%$ of respondents), 27\% recalled the Caucasian War of 1816-1864, which the Russian Empire waged against the highlanders. There are also extremely negative associations: $26 \%$ of respondents associate the North Caucasus with terrorism, 14\% with separatism. Nevertheless, it is worth noting that positive and neutral associations clearly prevail, which gives hope for the formation of a positive image of the North Caucasus within the country (Table 3).

Table 3. „What associations do you have when you hear about

the North Caucasus?” (multivariate choice) (Data source: Author's research, 2019)

\begin{tabular}{|l|c|}
\hline \multicolumn{1}{|c|}{ Answers } & $\%$ \\
\hline The mountains & 80 \\
\hline Islam & 45,6 \\
\hline Chechen conflict & 44,4 \\
\hline Lezginka & 42,2 \\
\hline Caucasian war & 26,7 \\
\hline Highlanders & 26,7 \\
\hline Terrorism & 25,6 \\
\hline Elbrus & 23,3 \\
\hline Dzhigits & 22,2 \\
\hline "Prisoner of the Caucasus" (film or book) & 14,4 \\
\hline Separatism & 14,4 \\
\hline The Caspian & 13,3 \\
\hline
\end{tabular}

We also asked respondents „What famous personalities from the North Caucasus do you know?" (Table 4). It should be noted the high awareness of Russian residents about famous people from the North Caucasus region, only 3\% of respondents said that they did not know anyone from the proposed list of personalities.

Table 4. „What famous personalities from the North Caucasus do you know?" (multivariate choice) (Data source: Author's research, 2019)

\begin{tabular}{|l|c|}
\hline \multicolumn{1}{|c|}{ Answers } & $\%$ \\
\hline Ramzan Kadyrov & 92,2 \\
\hline Khabib Nurmagomedov & 67,8 \\
\hline Shamil Basaev & 54,4 \\
\hline Akhmat Kadyrov & 52,2 \\
\hline Dzhokhar Dudaev & 46,7 \\
\hline Rasul Gamzatov & 46,7 \\
\hline Imam Shamil & 42,2 \\
\hline Ruslan Aushev & 30,0 \\
\hline Sultan Khan Girey & 12,2 \\
\hline Kosta Khetagurov & 10,0 \\
\hline Magomed Amin & 6,7 \\
\hline I don't know anyone & 3,3 \\
\hline
\end{tabular}

Among the most famous personalities who took the first three places are the Head of the Chechen Republic Ramzan Kadyrov (92\%), the famous champion Khabib Nurmagomedov (68\%) and the terrorist Shamil Basayev (54\%). In the fourth place by fame is the first President of the Chechen Republic Ahmad-Hadji Kadyrov. More than $40 \%$ of respondents said that they knew such representatives of the North Caucasus as: 
Rasul Gamzatov the Soviet Dagestan poet, Dzhokhar Dudaev the leader of the Chechen separatists, Imam Shamil the leader of the Caucasian tribes in the period of the Caucasian war of the $19^{\text {th }}$ century. The list also included the first president of the Republic of Ingushetia, Ruslan Aushev, the Circassian ethnographer Sultan Khan-Girey, the Ossetian poet Kosta Khetagurov, the leader of the Circassians during the Caucasian War, Magomed Amin. One of the aimes of the questionnaire was to identify stereotypes and ideas about the typical features of the peoples of the North Caucasus among Russians.

It should be noted that in the respondents' assessments, positive traits significantly prevailed: traditionalism (67\%), hospitality (64\%), religiosity (63\%), pride (51\%), and love of freedom (37\%). At the same time, $62 \%$ of the respondents also considered the peoples of the North Caucasus to be militant, and $24 \%$ unpredictable, which shows the survivability of some stereotypes about the peoples of the North Caucasus among residents of other parts of Russia. Speaking about media coverage of events in the North Caucasus, more than $1 / 2$ respondents noted that "there are enough both positive and negative news" from the region, $22 \%$ considered that there was more negative news, $14 \%$ of respondents answered that positive news prevailed. Only 12\% of respondents admitted that they did not pay attention to news from the North Caucasus (Figure 4). We see that neutral and positive assessments of news from the studied region prevail.

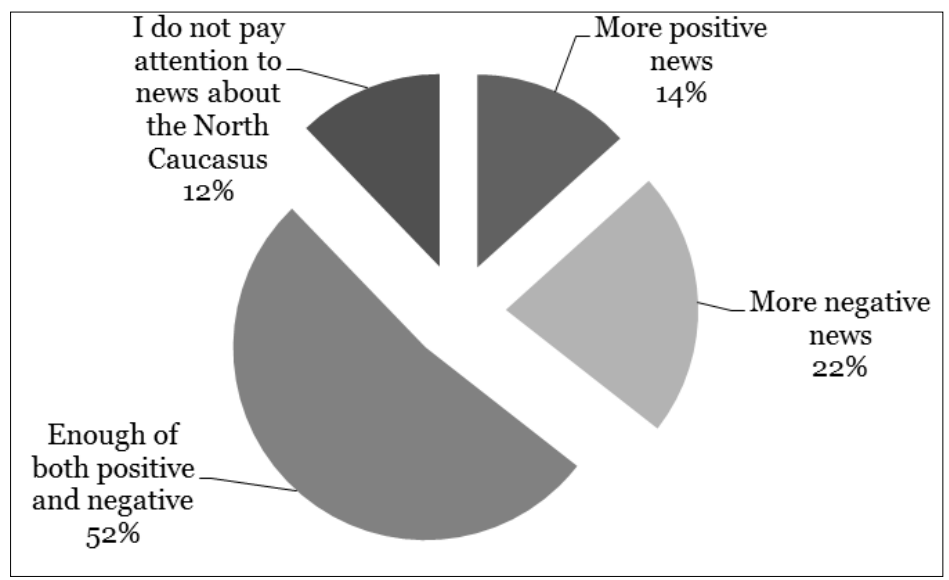

Figure 4. "In your opinion, are there more positive or negative news in the media about the North Caucasus?” (single choice)

Respondents were also asked about how, in their opinion, the socio-political situation in the North Caucasus has changed over the past five years. More than half (56\%) replied that the situation had changed for the better, $14 \%$ thought that the socio-political situation had changed for the worse, and $22 \%$ did not think that the sociopolitical situation had somehow changed. Thus, in public opinion, the prevailing view is that the situation is changing in a positive direction. An important question was to highlight the priority sectors in the North Caucasus which need to develop (Table 5). Respondents named tourism as the highest priority, the second place in importance, according to the respondents, was agriculture, the third - education. Meanwhile, more than a third of respondents (34\%) said that there are other problematic regions in Russia, and their development should be in priority. Among the important spheres for the North Caucasus were also named healthcare, oil production and refining, trade and transport. About $8 \%$ of respondents found it difficult to identify priority sectors for the development of this region. Important sectors of the economy of the Republic of Dagestan, such as ship repair and the fishing industry, gained 
about $3 \%$ of the vote. So, the majority of respondents share the opinion of the federal government about the need to develop tourism in the North Caucasus, while other industries are also called. At the same time, a significant proportion of respondents believe that other regions of Russia also need the attention of the authorities.

Table 5. „What spheres do you think are priority in the development of the North Caucasus of Russia?” (multivariate choice)

\begin{tabular}{|l|c|}
\hline \multicolumn{1}{|c|}{ Answers } & $\%$ \\
\hline Tourism & 47,8 \\
\hline Agriculture & 41,1 \\
\hline Education & 34,4 \\
\hline There are other problematic regions of Russia, they need to be in priority & 34,4 \\
\hline Healthcare & 30,0 \\
\hline Oil production and oil refining & 22,2 \\
\hline Transport & 18,9 \\
\hline Trade & 18,9 \\
\hline Difficult to answer & 7,8 \\
\hline Fishing industry & 3,3 \\
\hline Shipbuilding and ship repair & 3,3 \\
\hline
\end{tabular}

When asked if they would like to visit the North Caucasus, 69\% answered in the affirmative, including $21 \%$ of the respondents who would certainly visit the region, the rest were not against such a trip. Only $12 \%$ of respondents chose the answer option "I won't go for anything", while 15\% found it difficult to answer. Thus, the majority of respondents are considering the option of the trip to the North Caucasus.

Finally, we asked about preferred types of recreation that respondents would choose to visit the North Caucasus. Almost $1 / 2$ preferred excursion tourism (visiting the ancient city of Derbent, as well as the capital cities of the region) to skiing, which was chosen by a little more than $1 / 4$ of those surveyed (20\% are ready to climb the top of Elbrus, $5.5 \%$ would like to ski). Only $10 \%$ of the survey participants decided that they had no reason to go to the North Caucasus (Figure 5).

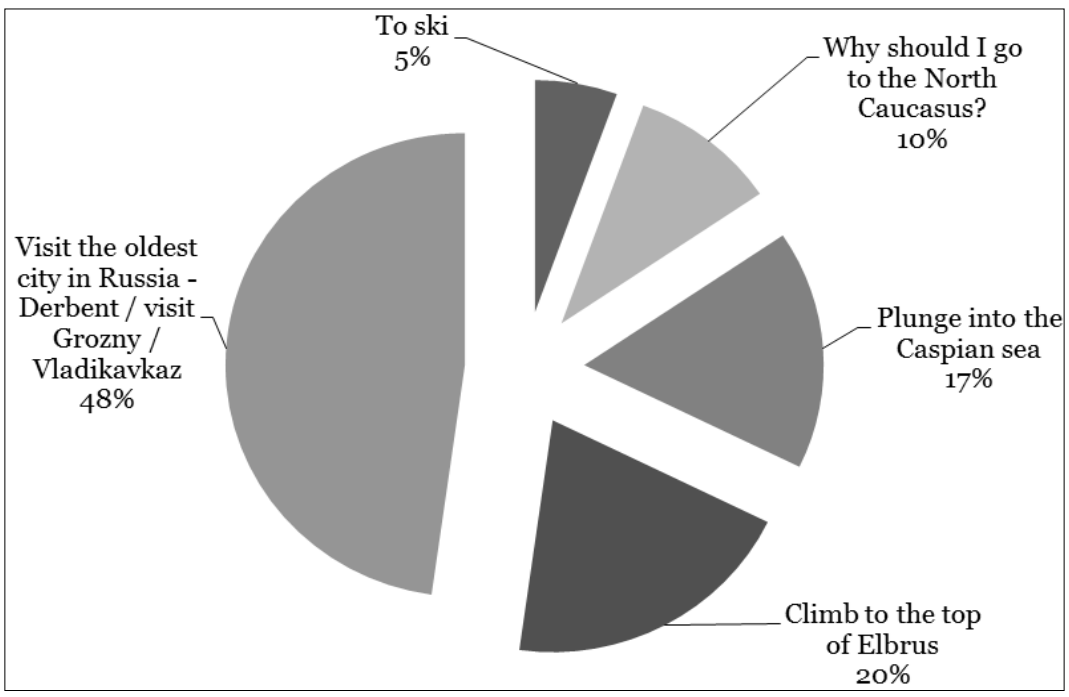

Figure 5. "If you had the opportunity to visit the North Caucasus, what type of vacation (tourism) would you prefer?" (single choice) 
Survey data showed that respondents from other regions of Russia, when visiting the North Caucasus, would be more enthusiastic about excursion tourism than vacationing in the skiing sector. But we can mention that the resources of cultural and ecological tourism of the North Caucasus are poorly used yet.

\section{CONCLUSION}

In general, the results of the study show an increase in the positive perceptions of the North Caucasus in the public opinion of Russians. Although, according to the respondents, there are enough positive and negative news in the media about the North Caucasus, the majority of respondents considered that the socio-political situation there has improved. Positive associations with the North Caucasus, as well as the identification of the positive traits inherent in the North Caucasian peoples, clearly prevail. Although we can see some stereotypes remained. Residents of Russia, including youth, are well aware of the history and significant personalities from the North Caucasus. All this gives hope for the formation of a positive image of the region within the country, which is so necessary for the development of tourism and socio-economic growth.

Statistics show that the resorts of the Krasnodar krai constitute serious competition to the North Caucasus. Moreover, the republics of the North Caucasus themselves compete with each other, JSC "Resorts of the North Caucasus" oversees projects for the development of mountain ski resorts, the same type of recreation areas are created in sufficient proximity. The „Dombai” and „Elbrus” resorts, traditionally in demand among lovers of skiing, need modernization and expansion of infrastructure, which requires significant investment, and in the Elbrus region also the solving of the land issue. Meanwhile, a region with a rich history is of great interest not only for sanatorium and skiing, but also for sightseeing tourism: the most ancient city of Derbent with the Naryn-Kala fortress, the village of Kubachi in Dagestan, the complex of medieval watchtowers of Vovnushki in Ingushetia and many other objects.

Opportunities for ecological and cultural tourism in Dagestan, North Ossetia and Ingushetia remain poorly exploited. The Chechen Republic in recent years has demonstrated a steady increase in the number of visits by both Russian and foreign tourists. The reputation of the region can be improved only in the long term, therefore the image formation should be considered consistently and strategically.

It is necessary to expand the information background of positive messages from the North Caucasus, conduct cultural and educational events, implement new economic projects, attract investment, and develop infrastructure.

\section{REFERENCES}

Andrades, L. \& Dimanche, F. (2017). Destination competitiveness and tourism development in Russia: Issues and challenges. Tourism Management, 62, 360-376.

Andreyanova, S. \& Ivolga, A. (2018). The Tourism Potential of the North Caucasus: the Formation, Characteristics and Development Prospects. GeoJournal of Tourism and Geosites, 22 (2), 347-358.

Anholt, S. (2008). Place branding: Is it marketing or isn't it? Place Branding and Public Diplomacy, 4, 1, 1-6.

Anholt, S. (2013). Beyond the Nation Brand: The Role of Image and Identity in International Relations. Exchange: Journal of Public Diplomacy, 2, 1, 6-12.

Beck, W. (2006). Narratives of World Heritage in Travel Guidebooks. International Journal of Heritage Studies, 12 (6), 521-535.

Bestaeva, I.M. \& Kodzaeva, L.M. (2018). Prospects for the development of tourism in the Republic of North Ossetia-Alania. Actual problems of the humanities and natural sciences, 10, 32-35.

Echtner, C. M. \& Ritchie, J.R.B. (1993). The measurement of destination image: An empirical assessment. Journal of Travel Research, 31 (4), 3-13.

Holland, E.C. (2016). Economic Development and Subsidies in the North Caucasus. Problems of PostCommunism, 63, 50-61. 
Hunter, C. (1997). Sustainable tourism as an adaptive paradigm. Annals of Tourism Research, 24 (4), $850-867$.

Jenes, B. (2008). Reconsidering the measurement of country image - theory and practice. FIKUSZ 2008 Business Sciences - Symposium for Young Researchers: Proceedings, ed. by László Áron Kóczy. Budapest: Óbuda University, Keleti Faculty of Business and Management, 65-80.

Kotler, P., Haider, D. \& Rein, I. (2002). Marketing Places. New York: Free Press, 400 p.

Matlovic, R. \& Matlovicova, K. (2012). The social relevance and branding of geography. Geografie, 117 (1), 33-51.

Matlovicova, K., Tirpakova, E. \& Mocak, P. (2019). City brand image: semiotic perspective a case study of Prague. Folia Geographica, 61 (1), 120-142.

Matyugina, E. G, Pozharnitskaya, O.V \& Vusovich, O.V. (2019). The natural potential as the basis for the formation of the tourist and recreational profile of the territory (on the example of the Republic of Dagestan). South of Russia: ecology, development, 14, 2 (51), 132-149.

Novenkova, A. M. \& Kalenskayaa, N. (2015). The Formation of the model branding of the territory under an asymmetric institutional environment. Procedia Economics and Finance, 23, 1388 - 1393.

Pogorova, Z. M. \& Dudurgova, T. M. (2019). Tourism in the Republic of Ingushetia and its development prospects. Colloquium-journal, 14(38), 61-62.

Stepchenkova, S. \& Morrison, A.M. (2006). The destination image of Russia: From the online induced perspective. Tourism Management, 27 (5), 943-956.

Stylidis, D. (2018). Residents' place image: a cluster analysis and its links to place attachment and support for tourism. Journal of Sustainable Tourism, 26, 6, 1007-1026.

Tsereteli, E., Gobejishvili, R., Bolashvili, N., Geladze, V. \& Gaprindashvili, G. (2011). Crisis intensification of geoecological situation of the Caucasus Black Sea coast and the strategy of risk reduction. Procedia Social and Behavioral Sciences, 19, 709-715.

Visan, M. (2019). Spatial and territorial development planning: digital challenge and reinvention using a multidisciplinary approach to support collaborative work. Procedia Computer Science, 162, 795-802.

Yezhova, E.N. \& Maslyuk, D.S. (2018). The dominant image of the North Caucasus in the Russian segment of social networks. Strategic communications and business in politics, 4, 332-339.

*** Federal State Statistics Service (2019)., http://www.gks.ru/wps/wcm/connect/rosstat_main /rosstat/ru/ statistics/population/level/ (accessed 04.02.2020)

*** More than 230 thousand people visited „Arkhyz” resorts in Karachay-Cherkessia and „Elbrus-Berezengi” in Kabardino-Balkaria (in the Elbrus region) during the winter season, (2015). January 4 / Rostourism, https://www.russiatourism.ru/regions /? fedokr $=112 \&$ freg $=147 \&$ article $=7078$ (accessed 04.02.2020).

*** Resorts of the North Caucasus (2018) May 28. http://www.ncrc.ru/press-center/publikatsii/publikatsii-smi/ ia-regnum-realizatsiya-kurortov-armkhi-tsori-i-matlas-otodvigaetsya-na-2023-god.html? sphrase_id = 7282 (accessed 04.02.2020).

*** State program of the Russian Federation "Development of the North Caucasus Federal District”, (2019). As amended by Decree of the Government of the Russian Federation of February 11, 2019 No. 111. http://pravo.garant.ru/SESSION/PILOT/main.htm (accessed 02.02.2020).

** Strategy of socio-economic development of the North Caucasus Federal District until 2025, (2010). Approved by order of the Government of the Russian Federation of September 6, 2010 No. 1485-r, https://rg.ru/2010/10/05/skfo-site-dok.html (accessed 02.02.2020).

*** Strategy of the spatial development of the Russian Federation until 2025, (2019). Approved by order of the Government of the Russian Federation dated February 13, 2019 No. 207-r, http:/government.ru/ docs/35733/ (accessed 02.02.2020).

*** TASS: The development of the Elbrus resort in the KBR depends on the solution of the land issue, (2019). Resorts of the North Caucasus, April 2, http://www.ncrc.ru/press-center/publikatsii/publikatsiismi/tass-razvitie-kurorta- elbrus-v-kbr-zavisit-ot-resheniya-zemelnogo-voprosa.html? sphrase_id = 7283 (accessed 04.02.2020).

*** The construction of routes and cableways on Elbrus is estimated at 5.7 billion, (2019). Caucasian Knot, July 5 , https://www.kavkaz-uzel.eu/articles/337492/ (accessed 04.02.2020).

*** The number of citizens of the Russian Federation placed in collective accommodation facilities, (2019). EMISS. State statistics, https://fedstat.ru/indicator/44040 (accessed 04.02.2020).

*** The number of foreign citizens placed in collective accommodation facilities, (2019). EMISS. State statistics, https://fedstat.ru/indicator/44042 (accessed 04.02.2020).

*** The ski season at the „Veduchi” resort began with artificial snow, (2019). Caucasian Knot, January 4, https://www.kavkaz-uzel.eu/articles/329955/ (accessed 04.02.2020).

*** Caucasian Knot, (2020), https://www.eng.kavkaz-uzel.eu/ (accessed 04.02.2020).

Submitted:

22.10.2019
Revised:

25.02.2020
Accepted and published online 03.03.2020 